Dr. J. J. Maquet (IRSAC). The remaining delegates came from Nigeria and the Gold Coast. The Conference was also attended by a number of people resident in Achimota and Accra.

In linguistics the following papers were read: 'Plans for Research on the Languages of West Africa ' by H. J. Uldall (U.C.I.); ' Pronunciation of English in West Africa ' by P. D. Strevens (U.C.G.C.); ' National and Official Languages of the Gold Coast' by A. Spicer (U.C.G.C.); and 'Speech defects in the Accra district' by Mrs. C. McCallien (U.C.G.C.). An open session in linguistics was held for the discussion of linguistic surveys in West Africa. In anthropology the papers read were : 'Mouvements prosélytiques en Côte d'Ivoire' by B. Holas (IFAN, Abidjan); 'A Discussion of the Theory of Élites in a West African Context' by P. Morton-Williams (WAISER); 'Évolution de la Vie familiale dans une ville africaine: Cotonou' by J. Lombard (IFAN, Porto Novo); 'The Gramophone and Contemporary African Music in the Gold Coast' by J. H. Nketia (U.C.G.C.); and 'Structural Changes in the Northern Territories of the Gold Coast 'by D. Tait (U.C.G.C.). In economics the papers read were: 'The Process of Changes in Land Tenure in the Gold Coast' by R. J. H. Pogucki (Lands Department, Gold Coast); 'Problems of Economic Growth' by Miss P. Deane (Cambridge University); 'Approaches to Housing Policy' by Mrs. M. Niculescu and E. R. Rado (U.C.G.C.); 'Niger Agricultural Project at Mokwa in the Niger Province, Northern Region' by K. D. S. Baldwin (WAISER); 'Le Problème des Investissements privés en Afrique Occidentale ' by Professor G. Leduc (University of Paris); 'Industries and Development in Low-Income Territories ' by B. M. Niculescu (U.C.G.C.); ' The Gold Coast Economy in the Eighteen-Eighties' by H. J. Bevin (U.C.G.C.); 'The Mortgaging of Gold Coast Cocoa-Farms, I900-1954' by Miss P. Hill (WAISER); and 'Premiers Résultats d'une enquête sur le niveau de vie d'une population urbaine' by J. Mersadier (IFAN, Dakar). In geography two papers were read: ' The Demographic Consequences of Social Change' by A. A. Igun (Education Officer-Statistics-Western Region, Nigeria), and 'Population Patterns and Migration in north-west Sokoto Province' by R. M. Prothero (WAISER). In sociology the papers read were: 'The Housing Situation in Kumasi' by A. Sutherland (Town Planning Officer, Kumasi); 'Begging and Destitution in the Towns of the Gold Coast' by Miss M. Clarkson (Senior Welfare Officer, Kumasi); 'Sociological Analysis of West African Political Parties' by P. C. Lloyd (WAISER); 'The 1954 General Election: A Public Opinion Survey in Accra' by W. B. Birmingham and G. Jahoda (U.C.G.C.); and 'The Muslim Vote in the Accra Constituencies' by J. H. Price (U.C.G.C.). Professor B. J. Garnier (U.C.I.) read a paper sent by Mrs. E. M. Chilver (C.S.S.R.C.) on 'The East African Institute of Social Research '; Professor W. O. Brown (Boston University) gave an informal talk on the 'The Development and Present Status of African studies in the U.S.A.'; and Dr J. J. Maquet (IRSAC) gave a brief communication on IRSAC and the forthcoming CCTA Conference at Bukavu.

It is expected that the Proceedings of this Conference will be published by the early autumn of this year after the publication of the proceedings of the Third Annual Conference, which took place in 1954 .

[Communicated by Philip Dark, Secretary, Executive Committee.]

\title{
Social Science Conference, University of Natal
}

A CONFERENCE on problems of Social Research in South Africa was held in Durban from 12-16 July 1954, at the invitation of the University of Natal. It was attended by representatives of universities, government departments, and institutions in the Union of South Africa and Southern Rhodesia interested in social sciences. The Principal of Natal Uni- 
versity, Dr. E. G. Malherbe, in his opening address, defined the purpose of the conference as follows :

(I) To assist social scientists in South Africa to get to know each other; (2) to provide an opportunity for delegates to learn at first hand of each other's work, in Government departments as well as in the universities; (3) to stimulate frank and open discussion of the problems hampering social research in the Union; (4) to attempt to reach agreement on social research priorities; ( $)$ to give delegates an opportunity of meeting Professor E. de S. Brunner of Columbia University and Professor C. R. Nixon of the University of California.

Introducing Professor Brunner and Professor Nixon, Dr. Malherbe said that they had come to Natal to assist in launching the Advanced Social Science Training Project, which was designed to prepare selected post-graduate research scholars to initiate, conduct, and supervise projects requiring interdisciplinary co-operation. The training scheme was supported by the National Council for Social Research, and was also being generously assisted by the Carnegie Corporation of New York and the Ford Foundation. In discussing research needs and priorities, Dr. Malherbe emphasized the need for trained investigators and the practical encouragement of post-graduate training. In this connexion he referred to the Institute for Social Research recently established in the University of Natal, where post-graduate training would be given, and interdisciplinary training would be emphasized. The organizer and secretary of the Institute, who was also the organizer of the Conference, Mr. Kenneth Kirkwood, had been appointed to the Rhodes Chair of Race Relations at Oxford; this appointment, though a great loss to the Institute and to the University, could be regarded also as a tribute.

In the course of the Conference papers were presented and discussed on such subjects as: Government departments and social research; co-ordination of social research in South Africa; sampling problems; economic research; educational research; research in industrial relations; problems of research among non-Europeans; the organization of social research in the United States. A number of committees studied methods and techniques, problems and priorities in economic, psychological, and educational research, training and employment of research workers, research in government and administration in South Africa.

In summarizing the Conference, Professor Brunner noted that problems of racial tensions had clearly been a major concern, though different disciplines approached them in different ways. He suggested that research was one means whereby divisions between the different groups in the community might be bridged. He touched briefly on a number of topics which had been discussed, and on the practical value of systematic studies of such questions as the utilization of man-power in relation to the employment of Europeans and non-Europeans; he emphasized the value of community and regional studies, involving co-operation between several institutions, and spoke of the utilization of research, and the benefits which would accrue to the Government and the nation from the prosecution of intense social research.

\section{Education in the United Kingdom Dependencies ${ }^{\mathrm{I}}$}

A RECENT publication of the Central Office of Information gives a comprehensive account of policy, objectives, and achievement in the field of education in the United Kingdom dependencies. A brief historical survey stresses the point that educational progress in the dependencies has always been closely linked to developments at home, and that the history of education in most of the nineteenth-century colonies might be described in almost the same terms as an account of public education in England and Wales in the same period. In

I Published by the Reference Division, Central Office of Information, London, September 1954 (RF. P. 2605.) 